Scientia Marina 85(4)

December 2021, 257-270, Barcelona (Spain)

ISSN-L: 0214-8358

https://doi.org/10.3989/scimar.05180.022

\title{
Small-scale fisheries in Madeira: recreational vs artisanal fisheries
}

\author{
Roi Martínez-Escauriaza ${ }^{1}$, Francesca Gizzi ${ }^{2}$, Lídia Gouveia ${ }^{3}$, Nuno Gouveia ${ }^{4}$, Margarida Hermida ${ }^{1,2}$ \\ ${ }^{1}$ Oceanic Observatory of Madeira, Agência Regional para o Desenvolvimento da InvestigaçãoTecnologia e Inovação, \\ (ARDITI), Edifício Madeira Tecnopolo, Caminho da Penteada, 9020-105, Funchal, Madeira, Portugal. \\ (RME) (Corresponding author) Email: roimartinez@ hotmail.com. ORCID-iD: https://orcid.org/0000-0003-1219-9937 \\ (MH) Email: margarida.hermida@mare-centre.pt. ORCID-iD: https://orcid.org/0000-0002-0259-109X \\ ${ }^{2}$ MARE - Marine and Environmental Sciences Centre, Agência Regional para o Desenvolvimento da Investigação, \\ Tecnologia e Inovação (ARDITI), Edifício Madeira Tecnopolo, Caminho da Penteada, 9020-105, Funchal, Madeira, Portugal. \\ (FG) Email: francesca.gizzi@ mare-centre.pt. ORCID-iD: https://orcid.org/0000-0001-9447-8694 \\ ${ }^{3}$ Direção de Serviços de Monitorização, Estudos e Investigação do Mar (DSEIMar) Direção Regional do Mar, Lota do \\ Funchal $1^{\circ}$ piso, Rua Virgílio Teixeira, 9004-562, Funchal, Madeira, Portugal \\ (LG) Email: lidia.gouveia@madeira.gov.pt. ORCID-iD: https://orcid.org/0000-0001-6904-7673 \\ ${ }^{4}$ Direção Regional de Pescas, Direção de Serviços de Inspeção e Controlo, Edifício da Sociedade Metropolitana de Câmara \\ de Lobos, Praça da Autonomia, 9300-138, Câmara de Lobos, Madeira, Portugal \\ (NG) Email: nuno.gouveia@ madeira.gov.pt. ORCID-iD: https://orcid.org/0000-0003-4633-4674
}

\begin{abstract}
Summary: Small-scale recreational and artisanal fisheries are popular activities in the Autonomous Region of Madeira and to date no information is available on their impact on regional coastal ecosystems. Through fishers' surveys and official registers of fish landings, we described and characterized these fisheries in Madeira, comparing artisanal and recreational fisheries. In 2017, artisanal boats landed 91 species in fishing ports, while recreational catches landed 58 species. The most frequent catches were Dentex gibbosus, Phycis phycis and Pagrus pagrus for artisanal fishery and P. pagrus, Serranus atricauda and Diplodus spp. for recreational fishery. Comparing the same techniques, artisanal fishery always showed higher catch per unit effort values than recreational boat fishery. Nevertheless, the low number of artisanal fishery boats in comparison with the recreational ones reflected the lower total landings of the artisanal fishery, which in 2017 were 62.3 $\mathrm{t}$, compared with the $509.8 \mathrm{t}$ estimated catches for the recreational fishery. Though the estimated recreational fishing data were based on surveys and thus subject to various biases, this activity seems to negatively affect coastal ecosystems and, together with artisanal fishing, exerts a combined pressure on targeted species. Improved legislation for both fisheries is essential for an appropriate management of resources.
\end{abstract}

Keywords: recreational boat fishery; artisanal fishery; Madeira; Portugal; species catch composition; SSF.

Pesca de pequeñas embarcaciones en Madeira: recreativa frente artesanal

Resumen: La pesca recreativa y artesanal a pequeña escala (small-scale fisheries - SSF) es una actividad común en la Región Autónoma de Madeira de la que hasta la fecha, no se dispone de información sobre su impacto en los ecosistemas costeros regionales. A través de encuestas a pescadores y los registros oficiales de descargas de las especies capturadas, fue posible describir y caracterizar esta modalidad de pesca en la región y comparando la pesca artesanal con la recreativa. En 2017, las embarcaciones artesanales registraron descargas de 91 especies diferentes, mientras que en las capturas recreativas se contabilizaron 58 especies. Las capturas más frecuentes fueron Dentex gibbosus, Phycis phycis y Pagrus pagrus para la pesca artesanal, y P. pagrus, Serranus atricauda y Diplodus spp. para la recreativa. Al comparar las mismas técnicas coincidentes en las dos modalidades de pesca, se observó que en la pesca artesanal siempre presentó valores de CPUE más altos que la recreativa embarcada. Aún así, debido al bajo número de embarcaciones artesanales, se observó que los valores anuales de descargas totales para esta pesquería, son mucho menores que los estimados para la pesca recreativa embarcada (en 2017 fueron de $62,3 \mathrm{t}$ en pesca artesanal, mientras que lo estimado para la pesca recreativa fueron 509,8 t). A pesar de que los datos estimados de pesca recreativa se basaron en encuestas y, por lo tanto, están sujetos a varios sesgos, esta actividad parece que puede afectar a los ecosistemas costeros, que junto con la pesca artesanal, puede ejercer una presión importante sobre las especies objetivo. Adecuar la legislación en ambas pesquerías es fundamental para poder realizar una gestión adecuada de los recursos.

Palabras clave: pesca con embarcaciones de recreo; pesca artesanal; Madeira; Portugal; composición de la captura de especies.

Citation/Como citar este artículo: Martínez-Escauriaza R., Gizzi F., Gouveia L., Gouveia N., Hermida M. 2021. Sma1l-scale fisheries in Madeira: recreational vs artisanal fisheries. Sci. Mar. 85(4): 257-270. https://doi.org/10.3989/scimar.05180.022

Editor: V. Stelzenmüller.

Received: March 5, 2021. Accepted: September 17, 2021. Published: November 26, 2021.

Copyright: ( $\odot 2021$ CSIC. This is an open-access article distributed under the terms of the Creative Commons Attribution 4.0 International (CC BY 4.0) License. 


\section{INTRODUCTION}

Coastal habitats are one of the most productive and valued ecosystems in the world (Costanza et al. 1997), but they are seriously threatened by factors such as habitat loss and degradation, pollution, overexploitation, species introduction, climate change and fisheries (Suchanek 1994, Cooke and Cowx 2006). Recreational and artisanal fisheries are often concentrated in coastal regions, where multiple uses of natural resources and continued overexploitation and degradation by human activities require increased efforts on the part of fisheries and coastal management (Lazzari et al. 2021). Until recently, it was thought that catches of recreational fisheries were significantly lower than those of commercial fisheries. Global fish catches have been estimated to be $14 \%$ higher if recreational fishing is added to commercial catches (Hyder et al. 2018). However, recent studies have shown that in some areas recreational catches are similar or even higher (Cooke and Cowx 2004, Zeller et al. 2008, Pita et al. 2018).

Recreational boat fishing together with the artisanal fishery are included in the category of small-scale fisheries (SSF), which is defined by the Common Fisheries Policy as "fishing carried out by fishing vessels of an overall length of less than $12 \mathrm{~m}$ without using towed fishing gear" (European Parliament 2014). The SSF boats usually use passive fishing gear targeting a wide range of pelagic and benthic coastal species, mostly demersal species, and usually resulting in small catches (Lloret et al. 2018). SSF is often considered more sustainable than large-scale fisheries because it involves smaller catches and has lower discards and lower annual fuel consumption (Lloret et al. 2018). However, SSF affects the fish populations from coastal regions (even if on a smaller scale than large-scale fisheries) and contributes to the decline of global fish stocks (Coleman et al. 2004, Cook and Cowx 2006, Morales-Nin et al. 2010, Castro et al. 2019).

SSF is an important socioeconomic activity in the Autonomous Region of Madeira (RAM) and has been an important factor in the success of human colonization of the region (Correia and Mendes 2000). Madeira is characterized by extremely vulnerable ecosystems due to the scarcity of benthic habitats, mainly restricted to the insular shelf and seamounts (Mata et al. 2013). Also, it has a coastline with high cliffs where access to the sea is sometimes difficult, especially on the north coast where the sea is rougher and the weather more unstable. These characteristics strongly influence the fisheries, limiting both the diversity and abundance of resident fishes and the viable fishing methods (Hermida and Delgado 2016). Fisheries in this archipelago are managed by the use of selective fishing techniques, controlled fishing effort and limited development of industrial fishing, to avoid putting ecosystems and resources at risk (DGRM 2018). Due to the low abundance of coastal and demersal resources, Madeiran fisheries are greatly dependent on the exploitation of a few fish species, including large pelagic migratory fishes, especially bigeye tuna, Thunnus obesus, Lowe, 1839, skipjack tuna, Katsuwonus pelamis (Linnaeus, 1758), and albacore, Thunnus alalunga
(Bonnaterre, 1788), small pelagic fishes (mainly the blue jack mackerel, Trachurus picturatus, Bowdich, 1825 and the Atlantic chub mackerel, Scomber colias, Gmelin, 1789) and deep-water species (the scabbardfishes Aphanopus carbo Lowe, 1839 and A. intermedius Parin, 1983) (Hermida and Delgado 2016, Tejerina et al. 2019).

Artisanal fishery uses multispecies techniques, mainly traps, longlines and hand lines. However, the Madeiran artisanal fleet is characterized by boats with a multigear licence that permits them to modify their capture techniques to complement their usual catches with other species such as deep-water fishes or large pelagic migratory fishes (DGRM 2018). The multigear techniques mean that fishers are able to adapt to dynamic environmental conditions according to the season and to the presence of different resources, optimizing the performance. A related problem is the difficulty of carrying out accurate monitoring directed at this multigear fishery (Battaglia et al. 2010), to better ascertain the real biomass extracted.

Recreational fishery is a sector that is rapidly growing in Madeira and encompasses modalities, such as boat fishing, shore angling, shellfish gathering and spearfishing (Font et al. 2012, Martínez-Escauriaza 2020a,b).

Despite the social and economic benefits related to these fisheries (Shon et al. 2015), they also involve significant ecological risks, including overfishing and habitat disturbance (Coleman et al. 2004). To reduce these problems, fishery legislation was introduced and implemented in Madeira in 1973 (National Legislative Decree $\mathrm{N}^{\circ}$ 9/73, 6 January 1973) for artisanal fishery and only in late 2016 (Regional Legislative Decree $N^{\circ} 484 / 2016$, 14 November 2016) for the recreational fishery. The legislation should reduce the ecological impact of the two fisheries, imposing restrictions on fishing methods and techniques, total catch limits, the minimum legal landing size for certain species, closed seasons and forbidden areas and species (Lloret et al. 2018). Moreover, the legislation for the recreational fishery includes the need for a recreational fishing licence issued by the Regional Fisheries Directorate (DRP).

To date, there are no studies about boat recreational or artisanal SSF in Madeira. For the first time, in this study, the differences and similarities between these activities are highlighted. We analysed artisanal fisheries in the Madeira archipelago from 2013 to 2019, describing the basic characteristics that include the fleet structure, fishing techniques and catch composition. We assessed the catch composition, effort and social characteristics of boat recreational fishery by analysing information obtained from interviews with fishers in 2017. Finally, we propose some measures that should be implemented in order to improve fisheries management.

\section{MATERIALS AND METHODS}

\section{Study area}

The archipelago of Madeira $\left(30-33^{\circ} \mathrm{N}\right.$; Fig. 1) is located in the eastern Atlantic where, together with the Azores, Canary Islands and Cape Verde, it constitutes 
the Macaronesia biogeographic region. The archipelago covers only about $5.4 \%$ of the emerging lands of Macaronesia, and it is administratively formed by the main island of Madeira, Porto Santo, and the uninhabited Desertas Islands and Selvagem Islands (Mata et al. 2013).

\section{Data collection}

\section{Artisanal fisheries}

Official fleet data were obtained through the DRP registries and include fish landings, the number of boats and their characteristics (fishing gear, gross tonnage, length overall (LOA) and engine power). The three artisanal purse seiners that catch small pelagic fishes in the region were not considered in this study because their LOA was higher than $12 \mathrm{~m}$ and they were therefore not included in SSF (Tejerina et al. 2019).

A total of 161 surveys of artisanal fishers from 29 different boats were recorded between 2013 and 2018 (for more details, see the survey in Supplementary Information 1). The questionnaires were carried out in the port by DRP technicians when the boats were returning from their fishing activity. The frequency of the surveys was irregular because it was dependent on the presence of the technician at the moment of arrival, which usually happens late at night. Moreover, the surveys were not mandatory, and many fishers refused to answer, further reducing their frequency. The aim of the survey was to obtain general knowledge of the activity and its impact, including questions on the date, boat, duration of the fishing operations (days/hours), fishing grounds and average depth (m), fishing gear and bait type, number of fishers per day and fish discards, including their destiny and the species (Supplementary Information 1). For each fishing trip performed between 2013 and 2019, data on the targeted species, total catch weights and their economic value were obtained from DRP records of fish landings. Using the duration of the fishing operation and the total catch weight, the catch per unit effort (CPUE) was calculated in $\mathrm{kg}$ per boat per hour for the most used gears. The CPUE was calculated only for the boats surveyed by the technicians. Unfortunately, the lack of information in the DRP registers on the duration of each fishing trip did not allow us to estimate the total effort of the fleet.

Using the economic value of each species and its total weight, it was possible to calculate the profit for each species $(€ / \mathrm{kg})$. Summing up the annual profit of all the species, we obtained the total profit of the catches for each year.

In addition, between 2013 and 2019, DRP technicians sampled the boat catches at the fishing port 163 times, recording the size of each fish collected (total length to the nearest $\mathrm{cm}$ ) and the weight of all fish from each species (to the nearest $0.1 \mathrm{~kg}$ ) for a total of 56 species landed. The average size, standard deviation and maximum and minimum length were calculated for each species. To estimate the average weight of each species for each sampling, the total weight of each species was divided by the total number of individuals belonging to that species. The average weight for each

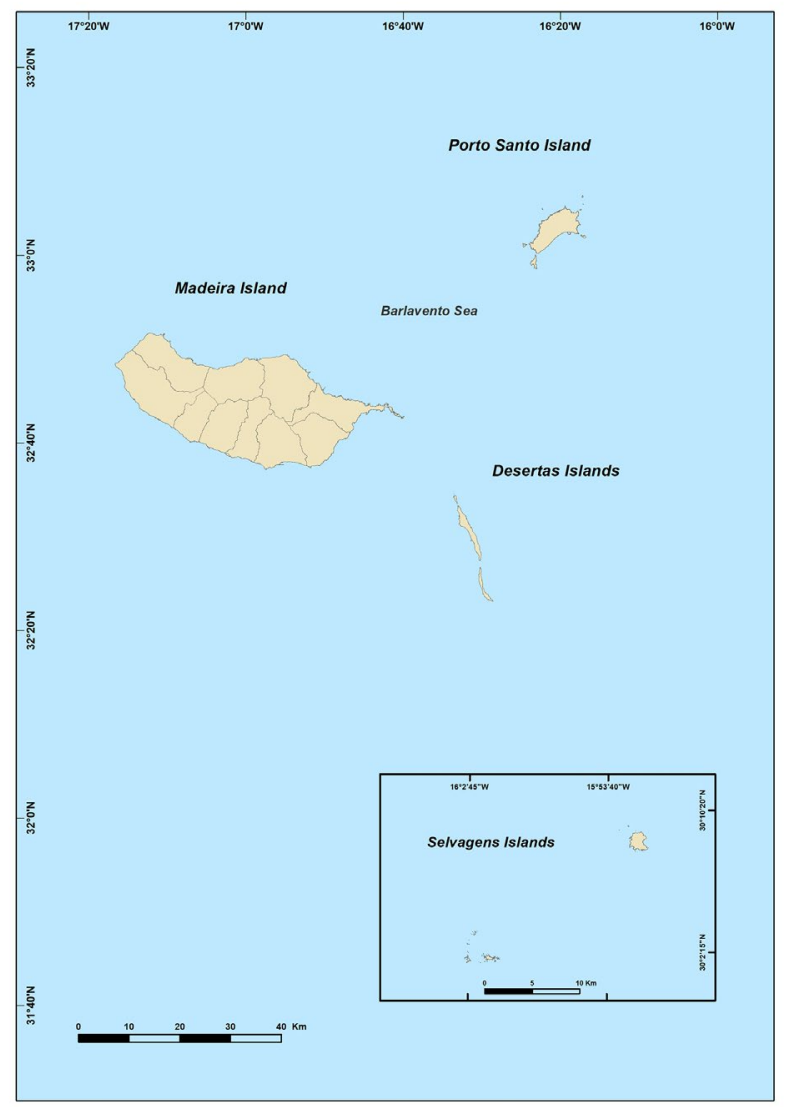

Fig. 1. - Archipelago of Madeira.

species was obtained by adding the average weights obtained for each sampling and dividing the total by the total number of samplings. The weight percentage of each species was calculated as a proportion of the total catch weight for the whole study period.

The number of boats, their characteristics, fishing trip duration (day/hours), CPUE (kg/hour), seasonality and main target species were compared among fishing methods.

\section{Recreational boat fishing}

To estimate the total number of recreational fishing boats present in the study area, we used the number of annual and monthly licences issued in 2017, obtained from the DRP. To characterize the recreational boat fishery, a survey programme was developed in 2017 and 152 fishers were surveyed: 90 when they were obtaining their licences in DRP offices and 62 when they returned from their fishing activity in the marinas, docks or beaches. The questionnaire (survey in Supplementary Information 2) collected basic demographic information of the fishers and data related to the activity, including fishing frequency (number of trips per year), effort (average number of hours per trip), average weight of the catches, the fishing methods used, the most frequently caught species and general opinions about the activity and associated legislation. Using only the data obtained in the DRP offices (90 surveys), 
we calculated the total effort for each boat (average duration of fishing trips in hours $\times$ average number of annual fishing operations) and CPUE measured in weight $(\mathrm{kg})$, which is the amount of fish caught per boat per hour (the average catch weight per fishing trip was divided by the average duration of the trips). Also, to calculate the total effort and CPUE, we only used data from anglers surveyed when obtaining their licences in the DRP office, as interviewing the fishers during or after the activity increases the probability of finding people that fish more frequently. Fishers with greater activity (avid fishers) are more likely to answer than those with lower activity and usually with lower catches, resulting in an avidity bias (Tarrant and Manfredo 1993). Because all fishers must obtain a licence to perform the activity, performing the surveys in the DRP office allowed us to interview a more representative sample of fishers, thus reducing avidity bias due to the greater heterogeneity of the fishers surveyed.

By multiplying the number of recreational fishing licences issued by the DRP in 2017 (both annual and monthly) by the average effort for each modality acquired from the surveys, we obtained the total effort of the Madeiran recreational fishing fleet for 2017. Multiplying the total effort obtained by the average CPUE, we estimated the total catch of the recreational boat fishery in Madeira in 2017.

Knowledge of the species most caught by each fisher interviewed, obtained from the list of species most frequently caught present in the survey (for more details, see Supplementary Information 2), allowed us to estimate the percentage of each caught species. Even if these estimated data are not very accurate, they give us an idea of the composition of the catches in recreational fishery.

The characteristics of boats, fishing trip duration, CPUE (kg/hour), seasonality and main target species were compared between the fishing methods.

\section{RESULTS}

\section{Fisheries characteristics}

\section{Professional artisanal fishery}

A total of 73 artisanal boats were registered in Madeiran ports from 2013 to 2019 , but only 28 of them went fishing during all (or almost all) of the selected period. Not all the artisanal boats with the multigear licence have demersal and coastal fishes as target species. In 2019, 54 boats requested the multigear licence but only 40 of them reported the landing of coastal species.

The first year analysed (2013) showed a larger fleet (46 boats) and lower participation (360 fishing trips in total) compared with the following considered years. The number of boats remained quite stable over the years, with the exception of 2014, when there were only 33 boats (Fig. 2). However, from 2016 to 2018 fishing operations increased from 540 to 1096, and consequently the catch weight and economic profits of the fishing market were higher, even with a similar number of boats (45 in both 2016 and 2018).

The boats were generally small in size, with an LOA of between 3.2 and $12 \mathrm{~m}(6.68 \mathrm{~m} \pm 2.21 \mathrm{~m}$, average $\pm \mathrm{SD}$ ), a gross tonnage of between 0.32 and $21 \mathrm{t}(3.63 \pm 2.29 \mathrm{t})$ and a power of 3 to $45.47 \mathrm{Kw}$ $(39.43 \pm 36.01 \mathrm{Kw})$. The small boat sizes limit travel distances, especially in winter. Thanks to the archipelago's mild climate, fishing takes place all year round, but there is an increase in fishing operations in spring and summer.

Four fishing methods targeting coastal fishes were identified (Table 1), and all of them used small pelagic fishes (mainly Scomber colias) and cephalopods as bait, sometimes dead and sometimes alive (especially in the rod and line method). The characteristics of the boats and fishing activities are shown in Table 1.

\section{Recreational boat fishery}

The DRP issued 789 recreational licences (761 annual and 28 monthly) in the RAM in 2017, of which 97 were processed in Porto Santo. The participation rate in 2017 was $0.3 \%$ for the RAM as a whole $(0.27 \%$ for Madeira Island and $1.87 \%$ for Porto Santo). The DRP issued 727 licences in the RAM (707 annual and 20 monthly) in 2018 and 673 (658 annual and 15 monthly) in 2019.

The interviews performed in $2017(\mathrm{n}=152)$ revealed that $36.1 \%$ of fishers possessed only the boat licence, $34.2 \%$ had licences for boat and shore angling, $10.5 \%$ for boat and spearfishing, and 19\% for all the three categories (boat, shore angling and spearfishing). Only one person was found without a licence.

Most of the recreational fishers $(68.8 \%)$ chose to fish accompanied, a small fraction preferred to fish alone $(8.6 \%)$ and the rest $(22.5 \%)$ chose both options. Of those surveyed, $35.3 \%$ preferred to fish during weekends, $8.6 \%$ during the week and $56 \%$ had no preference. The majority of the fishers $(76.9 \%)$ undertook the activity throughout the entire year, with no seasonal preference, $20.2 \%$ preferred the warmer seasons (spring-summer) and only $2.8 \%$ the colder seasons (autumn-winter). Fishing areas were represented by the south coast of Madeira (32.1\%), the north coast $(18.7 \%)$, the whole island (28\%), Porto Santo (5.8\%) and around the Desertas Islands (3.5\%). The fishers performed the activity at $2.3 \pm 2.0 \mathrm{~nm}$ from the coast to a depth of $169.1 \pm 217.4 \mathrm{~m}$. The most common techniques were rod and reel, trolling, jigging and hand line. Characteristics of boats and fishers using these modalities are shown in Table 2.

Another traditional practice adopted by recreational fishers is the squid hand-jig line, characterized by very selective gear. A cephalopod usually caught with this practice all year round is the common squid Loligo vulgaris, Lamarck, 1798, which is sometimes kept alive for later use in Dentex gibbosus (Rafinesque, 1810) onboard fishing. However, this practice is mostly seasonal, since fishers take advantage of migrations and passage of other cephalopods that occur along 
Table 1. - Artisanal fishing techniques and characteristics (number of interviewed boats, number of surveys, LOA, usual fishing areas S, South; B, Barlovento; D, Desertas; PS, Porto Santo; M, Madeira; PM, Paul do Mar; CG, Cabo Girão), fishing depth range, fuel expense, duration of the fishing trip, CPUE, seasonality and main target species). The data are shown as number or average \pm SD.

\begin{tabular}{|c|c|c|c|c|c|c|c|c|c|c|c|c|}
\hline 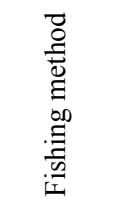 & 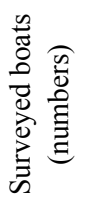 & 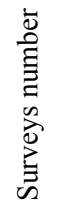 & 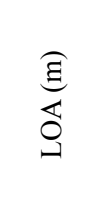 & 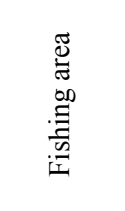 & 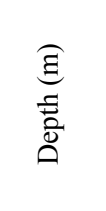 & 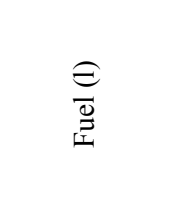 & 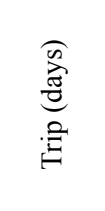 & 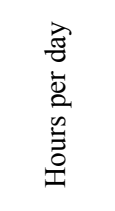 & 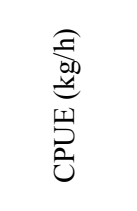 & 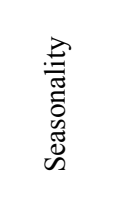 & 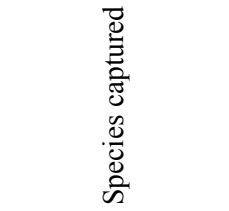 & . \\
\hline $\begin{array}{l}\text { Hand } \\
\text { line }\end{array}$ & 5 & 15 & $6.3 \pm 1.9$ & $\mathrm{~S}, \mathrm{~B}, \mathrm{D}$ & $60-150$ & $52.2 \pm 33.1$ & $4.1 \pm 3.4$ & $3.8 \pm 2.7$ & $4.9 \pm 2.3$ & $\begin{array}{l}\text { Spring } \\
\text { and } \\
\text { summer }\end{array}$ & $\begin{array}{c}\text { Dentex gibbosus, } \\
\text { Pargus pargus, } \\
\text { Serranus } \\
\text { atricauda. } \\
\text { Seriola } \text { sp., } \\
\text { Sphyraena } \\
\text { viridensis }\end{array}$ & $\begin{array}{l}\text { S. colias, } T \text {. } \\
\text { picturatus } \\
\text { and } \\
\text { cephalopods }\end{array}$ \\
\hline $\begin{array}{l}\text { Rod and } \\
\text { reel }\end{array}$ & 2 & 14 & $6.8 \pm 1$ & $\mathrm{D}, \mathrm{B}, \mathrm{PS}$ & $\begin{array}{c}110, \\
>200\end{array}$ & $45.3 \pm 38$ & $2.7 \pm 1$ & $4.9 \pm 0.4$ & $5.7 \pm 2.5$ & All year & $\begin{array}{c}\text { D. gibbosus, } \\
\text { P. pagrus, } \\
\text { Polyprion } \\
\text { americanus, } \\
\text { Seriola } \text { sp., } \\
\text { Conger conger }\end{array}$ & $\begin{array}{l}\text { S. colias } \\
\text { (dead and } \\
\quad \text { live) }\end{array}$ \\
\hline Longline & 29 & 123 & $6.6 \pm 2.2$ & $\begin{array}{l}\text { M, D, B, } \\
\text { PS }\end{array}$ & $60-100$ & $150.3 \pm 268.4$ & $4.2 \pm 2.3$ & $4.3 \pm 2.7$ & $13.2 \pm 25.8$ & All year & $\begin{array}{c}\text { Phycis phycis, } \\
\text { D. gibbosus, } P \text {. } \\
\text { pagrus }\end{array}$ & $\begin{array}{l}\text { S. colias, } T \text {. } \\
\text { picturatus } \\
\text { and } \\
\text { cephalopods }\end{array}$ \\
\hline Traps & 1 & 2 & 4.6 & PM, CG & $10-25$ & $43 \pm 46.7$ & 0.9 & & 1 & Winter & $\begin{array}{l}\text { Chromis limbata, } \\
\text { Muraena helena }\end{array}$ & S. colias \\
\hline
\end{tabular}

Table 2. - Recreational boat fishing techniques and characteristics (number of surveys, LOA, crew numbers, distance from the coast, fishing depth, expenses, duration of the fishing trip [hours and days per year], CPUE, seasonality and main target species). The data are shown as number or average \pm SD.

\begin{tabular}{|c|c|c|c|c|c|c|c|c|c|c|c|c|}
\hline 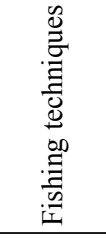 & 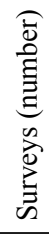 & 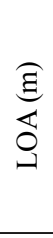 & 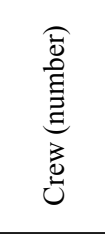 & 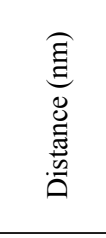 & 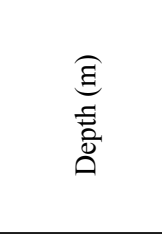 & 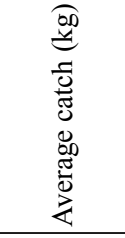 & 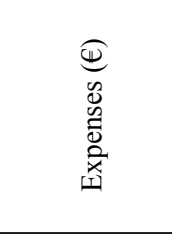 & 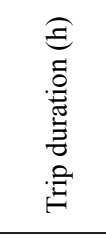 & 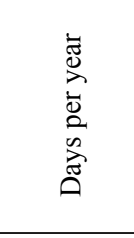 & 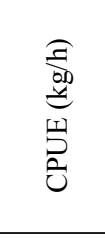 & 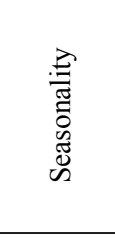 & 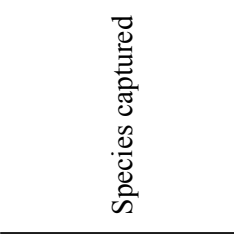 \\
\hline $\begin{array}{l}\text { Rod } \\
\text { and } \\
\text { reel }\end{array}$ & 63 & 5 & $2.7 \pm 0.9$ & $1.9 \pm 2.2$ & $147.1 \pm 104.3$ & $8.4 \pm 3.7$ & $618.4 \pm 788$ & $6.5 \pm 2.4$ & $63.6 \pm 57.8$ & $1.4 \pm 0.8$ & All year & $\begin{array}{c}\text { P. pargus, } S \text {. } \\
\text { atricauda, Balistes } \\
\text { capriscus }\end{array}$ \\
\hline $\begin{array}{c}\text { Troll- } \\
\text { ing }\end{array}$ & 10 & 6.5 & $2.9 \pm 0.9$ & $2.3 \pm 2.1$ & $161.7 \pm 93.5$ & $12.2 \pm 7.4$ & $710.5 \pm 874.2$ & $6.5 \pm 3.2$ & $61.5 \pm 80$ & $2.1 \pm 1.3$ & $\begin{array}{l}\text { Sum- } \\
\text { mer and } \\
\text { autumn }\end{array}$ & $\begin{array}{c}\text { Istiophoridae, } \\
\text { Thunnus sp., } \\
\text { Coryphaena } \\
\text { hippurus, Seriola } \\
\text { sp. }\end{array}$ \\
\hline Jigging & 23 & 5.2 & $3.2 \pm 1$ & $2.3 \pm 1.7$ & $145 \pm 61.5$ & $10.6 \pm 5.8$ & $968.7 \pm 1146.1$ & $7 \pm 3.1$ & $83.3 \pm 74.9$ & $1.6 \pm 1.1$ & All year & $\begin{array}{l}\text { Seriola sp., } \\
\text { S. viridensis, } \\
\text { P. pargus, } D . \\
\quad \text { gibbosus }\end{array}$ \\
\hline $\begin{array}{c}\text { Hand } \\
\text { line }\end{array}$ & 44 & 4.7 & $2.5 \pm 0.7$ & $2.2 \pm 2.4$ & $156.2 \pm 114.2$ & $9.1 \pm 5.5$ & $716.2 \pm 1179.8$ & $7.2 \pm 2.6$ & $77.8 \pm 81.2$ & $1.4 \pm 1.4$ & All year & $\begin{array}{c}\text { P. pargus, } S . \\
\text { atricauda, } \\
\text { Diplodus sargus }\end{array}$ \\
\hline
\end{tabular}

the coasts of Madeira in summer months. Of these, there are three main target species: the European flying squid, Todarodes sagittatus (Lamarck, 1798), the neon flying squid, Ommastrephes bartramii (Lesueur, 1821), and the orangeback squid, Sthenoteuthis pteropus (Steenstrup, 1855).

Finally, two surveyed fishers admitted to fishing with traps, a method that is not permitted for recreational fishing.

\section{Catch composition, size and weight}

\section{Professional artisanal fishery}

Between 2013 and 2019, a total of 91 species were landed in Madeira fishing ports by artisanal boats. The fish species belonged mostly to the Osteichthyes group (73) and only 6 species to the Chondrichthyes. The Sparidae family was the most abundant group, 
encompassing 14 different species. Moreover, 12 invertebrates, divided into 5 decapod arthropods and 7 molluscs (5 cephalopods and 2 gastropods) were identified.

Artisanal landings were characterized by abundant catches of $D$. gibbosus, Phycis phycis (Linnaeus, 1766) and Pagrus pagrus (Linnaeus, 1758). The evolution of the catches of the 10 species most caught by the artisanal fishery in the period 2013-2019 is shown in Figure 3. The increase in catches of D. gibbosus in the last two years is noteworthy, reaching 40 to $50 \mathrm{t}$, a more than tenfold increase since the start of the series and a higher recorded catches than that of any other species in any year of the series.

In Porto Santo, 16 different species of Osteichthyes were landed by the recreational boat fishery between 2013 and 2016, for a total of 3.9 t, representing only $1 \%$ of the catches recorded for the entire region. The most captured species was $P$. pagrus, followed by Balistes capriscus (Gmelin, 1789) and Sphyraena viridensis Cuvier, 1829 (Table 3).

\section{Recreational boat fishery}

From surveys of recreational fishers and their logbooks, a total of 58 species were identified, including 53 Osteichthyes, 3 Chondrichthyes and 4 invertebrates (3 cephalopods and 1 gastropod). Catches of Diplodus spp. were more abundant in recreational boat fishery than in artisanal fishery, whereas $D$. gibbosus and $P$. phycis were less common.

The detailed list of the species from both fisheries, together with their average size and weight (when available), are shown in Table 3 .

\section{CPUE, total catch, effort}

CPUE values $(\mathrm{kg} / \mathrm{h})$ for both fisheries can be consulted in Tables 1 and 2. Artisanal fishery landings increased over the years, starting with $30 \mathrm{t}$ in 2013, doubling the catch in 2017 (62.3 t) and tripling in the last years (Fig. 2). The total weight landed in the study period (2013-2019) was $393.8 \mathrm{t}$.

The average CPUE including all recreational boat fishing was $1.42 \pm 0.97 \mathrm{~kg} / \mathrm{h} /$ day. The average effort in 2017 (survey period) for annual and monthly boat fishing licences was $467.7 \pm 713.4 \mathrm{~h}$ and $42.5 \pm 20.5 \mathrm{~h}$, respectively. The total effort of the whole recreational fleet was $358823 \mathrm{~h}$, with $509.8 \mathrm{t}$ of total estimated catch. Recreational boats went fishing $58.3 \pm 61.4$ days per year and $6.86 \pm 2.82 \mathrm{~h}$ per day trip.

\section{Recreational boat fishers' characteristics and opinions}

With the exception of a single woman, all the fishers interviewed were male $(99.3 \%)$, and the majority $(96.7 \%)$ were residents of the RAM. Among them, almost half (47.3\%) lived in Funchal, a few (4.6\%) lived in Porto Santo, and the rest in other villages of the main island. The fishers' ages ranged from 18 to 75 , with an average age of $45.3 \pm 12.2$. The average fishing

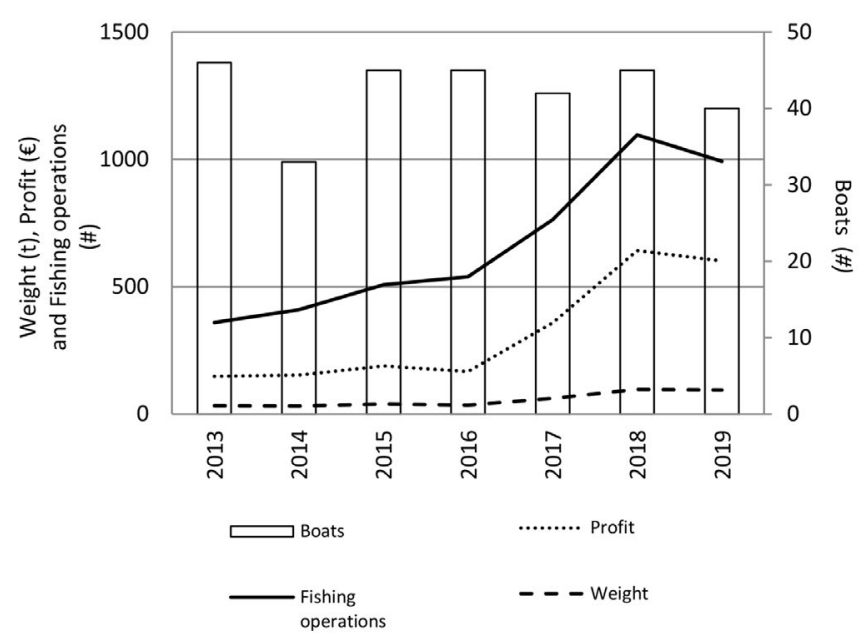

Fig. 2. - Evolution of total caught weight, total profit and fishing operations of the RAM artisanal fleet for each year considered (2013-2019).

experience of these fishers was $21.1 \pm 13.9$ years, including both veterans and beginners, and the average age at which they started fishing was $24.3 \pm 12.2$ years.

Most $(60.9 \%)$ were married, $26.4 \%$ were single, $11.9 \%$ divorced and one $(0.66 \%)$ was widowed. More than half of those interviewed had basic education $(56 \%)$, and of the other half $12.6 \%$ had higher education, $15.3 \%$ vocational training, $14.6 \%$ had completed secondary school and $1.3 \%$ had no formal education. More than half were employed (67.7\%), of whom $38.8 \%$ were private sector workers, $19 \%$ self-employed and $9.8 \%$ public sector workers. People outside the work force $(32.3 \%)$ included retirees (11.1\%), unemployed (19\%), people on disability benefits $(0.6 \%)$ and students $(1.3 \%)$. Of the surveyed fishers, $31.9 \%$ had either no income or less than $€ 500$, $36.8 \%$ between $€ 500$ and $€ 1000,21.3 \%$ a variable income and only $2.4 \%$ earned more than $€ 1500$. The average expenses related to the practice of recreational boat fishing were $€ 763.1 \pm 1054.7$ per year.

Most of the fishers $(97.6 \%)$ stated that they consumed their catch, $31 \%$ shared part of it, $20.1 \%$ sometimes released small-sized individuals or species without gastronomic value, and only a small percentage $(8.5 \%)$ stated that they sold their catches. A quarter of the fishers $(25.4 \%)$ considered that fish abundance had decreased over the years, $3.5 \%$ perceived an increase and most of them $(71.1 \%)$ noticed no difference. More than half $(56.8 \%)$ believed that the number of fishers practising the activity had increased in time.

Opinions about legislation concerning the fishery included the suggestion of increased control by authorities $(30.5 \%)$, the consideration that the price of licences was too high $(20 \%)$ and the proposal of increasing the maximum quantity of fishes caught $(12.9 \%)$. Only a few fishers $(9.4 \%)$ would have liked more information about fishery legislation, and a similar percentage suggested increasing the study of species biology. 
Table 3. - List of the species captured in the artisanal and recreational boat fishery (surveys and logbook), with the percentages (also for Porto Santo) of captures and average sizes and weights of species sampled in the artisanal fishery. Av, average; Sd, standard deviation; Min, minimum size; Max, maximum size; $n$, number of measured fishes.

\begin{tabular}{|c|c|c|c|c|c|c|c|c|c|c|c|c|c|c|}
\hline \multirow{3}{*}{ Scientific name } & \multicolumn{11}{|c|}{ ARTISANAL FISHERY } & \multicolumn{3}{|c|}{ RECREATIONAL BOAT } \\
\hline & \multicolumn{4}{|c|}{ Size $(\mathrm{cm})$} & \multicolumn{5}{|c|}{ Weight (kg) } & \multirow{2}{*}{$\begin{array}{c}\text { Artesanal } \\
\text { catches } \\
(\%)\end{array}$} & \multirow{2}{*}{$\begin{array}{c}\begin{array}{c}\text { Porto } \\
\text { Santo } \\
(\%)\end{array} \\
(2013- \\
2016) \\
\end{array}$} & \multirow{2}{*}{$\begin{array}{c}\text { Recreative } \\
\text { catches } \\
(\%)\end{array}$} & \multirow[t]{2}{*}{$\begin{array}{l}\text { Indiv. } \\
\text { recreative } \\
\text { logbook } \\
(\%)\end{array}$} & \multirow[t]{2}{*}{$\begin{array}{c}\mathrm{kg} \text { rec- } \\
\text { reative } \\
\text { logbook } \\
(\%) \\
\end{array}$} \\
\hline & \# & $\mathrm{Av}(\mathrm{SD})$ & Max & Min & $\begin{array}{c}\text { Samples } \\
\text { (number) }\end{array}$ & $\begin{array}{c}\text { Indiv } \\
\text { (number) }\end{array}$ & $\mathrm{Av}(\mathrm{SD})$ & Max & Min & & & & & \\
\hline \multicolumn{15}{|l|}{ OSTEICHTHYES } \\
\hline Abudefduf luridus & 65 & $10.3 \pm 1$ & 12 & 8 & 1 & 64 & 0.03 & & & 0.05 & 6.3 & & & \\
\hline $\begin{array}{l}\text { Acanthocybium } \\
\text { solandri }\end{array}$ & & & & & & & & & & 0.03 & 3.9 & 1.05 & & \\
\hline Acantholabrus palloni & & & & & & & & & & 0.01 & & & & \\
\hline Aphanopus carbo & & & & & & & & & & 0.32 & & & & \\
\hline Apogon imberbis & 46 & $32.6 \pm 9.3$ & 53 & 22 & 6 & 46 & $0.84 \pm 0.64$ & 1.87 & 0.07 & 0.06 & & & & \\
\hline Balistes capriscus & 726 & $36.9 \pm 5.3$ & 62 & 25 & 31 & 723 & $1.04 \pm 0.45$ & 2.64 & 0.52 & 2.11 & 16.8 & 4.42 & 9.17 & 12.81 \\
\hline Belone belone & & & & & & & & & & & & 0.21 & & \\
\hline Beryx decadactylus & 5 & $42.6 \pm 7.9$ & 54 & 32 & 2 & 5 & $2.63 \pm 0.82$ & 1.90 & 0.73 & 0.08 & & 0.21 & & \\
\hline Beryx splendens & 4 & $29.5 \pm 1.3$ & 30 & 27 & 1 & 4 & 0.3 & & & 0.08 & & 0.21 & & \\
\hline Bodianus scrofa & 84 & $42.9 \pm 7.2$ & 65 & 29 & 36 & 81 & $1.42 \pm 0.46$ & 2.60 & 0.80 & 0.36 & 6.2 & 0.21 & 0.48 & 0.98 \\
\hline Boops boops & & & & & & & & & & 0.01 & 0.8 & 0.84 & 0.06 & 0.012 \\
\hline Brama brama & & & & & & & & & & 0.01 & & & & \\
\hline Canthigaster rostrata & & & & & & & & & & & & & 0.61 & 0.049 \\
\hline Capros aper & 7 & $19.7 \pm 1$ & 21 & 18 & 1 & 7 & 0.23 & & & 0.01 & & & & \\
\hline Chromis limbata & 2811 & $12.8 \pm 1$ & 16 & 8 & 31 & 2811 & $0.04 \pm 0.01$ & 0.06 & 0.03 & 1.81 & 3.3 & 0.42 & 5.32 & 0.28 \\
\hline Conger conger & 336 & $111.1 \pm 20.2$ & 175 & 32 & 54 & 322 & $3.37 \pm 1.8$ & 6.20 & 1.33 & 2.52 & & & & \\
\hline Coryphaena hippurus & 26 & $68.7 \pm 25.2$ & 125 & 44 & 4 & 26 & $4.26 \pm 5.75$ & 12.90 & 0.77 & 0.13 & & 0.63 & & \\
\hline Dentex gibbosus & 3124 & $46.2 \pm 20$ & 97 & 19 & 174 & 2927 & $3.16 \pm 4.32$ & 9.20 & 0.04 & 31.19 & & 0.84 & 0.97 & 4.5 \\
\hline Dicentrarchus labrax & & & & & & 59 & & & & & & 0.02 & & \\
\hline Diplodus cervinus & 141 & $29 \pm 5.4$ & 39 & 17 & 19 & 690 & $0.57 \pm 0.19$ & 1.00 & 0.20 & 0.03 & & 0.42 & & \\
\hline Diplodus sargus & 797 & $27 \pm 4.8$ & 43 & 17 & 30 & 469 & $0.44 \pm 0.2$ & 0.75 & 0.06 & 0.45 & 2.3 & 5.89 & 0.06 & 0.033 \\
\hline Diplodus vulgaris & 495 & $22 \pm 5.8$ & 52 & 13 & 24 & 12 & $0.21 \pm 0.1$ & 0.43 & 0.09 & 0.55 & 5.7 & 5.05 & 1.28 & 0.36 \\
\hline $\begin{array}{l}\text { Epinephelus } \\
\text { marginatus }\end{array}$ & 12 & $61.1 \pm 19.1$ & 90 & 41 & 9 & 39 & $6.71 \pm 5.53$ & 14.60 & 2.10 & 0.21 & & & & \\
\hline $\begin{array}{l}\text { Gephyroberyx } \\
\text { darwinii }\end{array}$ & & & & & & & & & & 0.01 & & & & \\
\hline Gymnothorax spp. & 4 & $87 \pm 4.2$ & 93 & 83 & 1 & 186 & 1.23 & & & 0.02 & & & & \\
\hline $\begin{array}{l}\text { Helicolenus } \\
\text { dactylopterus }\end{array}$ & 286 & $27.9 \pm 5.6$ & 42 & 16 & 20 & 5 & $0.29 \pm 0.29$ & 1.20 & 0.40 & 0.39 & & 1.05 & 0.18 & 0.023 \\
\hline $\begin{array}{l}\text { Heteropriacanthus } \\
\text { cruentatus }\end{array}$ & 5 & $50.6 \pm 6.2$ & 58 & 42 & 3 & 1 & $2.03 \pm 0.64$ & 2.50 & 1.30 & 0.01 & & & & \\
\hline Katsuwonus pelamis & & & & & & & & & & 1.36 & & 0.63 & & \\
\hline Kyphosus sectatrix & 4 & $48.8 \pm 8.6$ & 58 & 40 & 1 & 1 & 1.67 & & & 0.03 & & 0.21 & & \\
\hline $\begin{array}{l}\text { Lepidocybium } \\
\text { flavobrunneum }\end{array}$ & & & & & & & & & & 0.01 & & & & \\
\hline $\begin{array}{l}\text { Lithognathus } \\
\text { mormyrus }\end{array}$ & 1 & 29 & 29 & 29 & 1 & 3 & 0.40 & & & 0.01 & & & & \\
\hline Istiophoridae & & & & & & 189 & & & & & & 0.42 & & \\
\hline $\begin{array}{l}\text { Merluccius } \\
\text { merluccius }\end{array}$ & 3 & $72.7 \pm 16.4$ & 85 & 54 & 2 & 154 & $4.05 \pm 2.19$ & 5.60 & 2.50 & 0.01 & & & & \\
\hline Mora moro & & & & & & & & & & 0.01 & & & & \\
\hline Mugilidae & & & & & & & & & & 0.11 & & 0.21 & & \\
\hline Mullus surmuletus & 291 & $31.2 \pm 4$ & 46 & 24 & 8 & 419 & $0.41 \pm 0.12$ & 0.63 & 0.27 & 0.06 & & 0.42 & 0.06 & \\
\hline Muraena augusti & 163 & $85.1 \pm 8.5$ & 113 & 66 & 16 & 8 & $1.44 \pm 0.31$ & 1.90 & 1.00 & 0.29 & & & & \\
\hline Muraena helena & 419 & $92.3 \pm 10.8$ & 135 & 65 & 48 & 2 & $2.39 \pm 1.28$ & 6.20 & 0.63 & 2.00 & & 0.21 & 0.18 & 1.04 \\
\hline Mycteroperca fusca & 2 & $50 \pm 25.5$ & 68 & 32 & 2 & 17 & $4.25 \pm 1.91$ & 5.60 & 2.90 & 0.44 & & 0.63 & 0.06 & 0.34 \\
\hline Nesiarchus nasutus & & & & & & & & & & 0.00 & & & & \\
\hline Oblada melanura & 24 & $26.7 \pm 1.5$ & 29 & 24 & 2 & 713 & $0.3 \pm 0.05$ & 0.29 & 0.22 & 0.02 & & 0.42 & & \\
\hline Pagellus acarne & 742 & $22.9 \pm 1.9$ & 33 & 16 & 35 & 1 & $0.16 \pm 0.04$ & 0.26 & 0.10 & 0.24 & & 4.00 & 3.1 & 0.68 \\
\hline Pagellus bogaraveo & 497 & $29.9 \pm 5.7$ & 53 & 20 & 45 & 4811 & $0.57 \pm 0.61$ & 1.45 & 0.17 & 0.66 & & 1.68 & & \\
\hline Pagellus erythrinus & 1 & 37 & 37 & 37 & 1 & 5580 & 0.7 & & & 0.01 & & 3.37 & 1.34 & 0.54 \\
\hline Pargus pargus & 5932 & $31.1 \pm 6.7$ & 86 & 14 & 150 & 261 & $1.33 \pm 5.99$ & 11.70 & 0.23 & 13.52 & 25.0 & 22.11 & 22.81 & 40.74 \\
\hline Phycis phycis & 6447 & $39.1 \pm 7.2$ & 64 & 13 & 111 & 24 & $0.81 \pm 0.32$ & 2.40 & 0.13 & 16.41 & 3.4 & 0.21 & 0.3 & 0.33 \\
\hline Polymixia nobilis & 261 & $32.2 \pm 4.4$ & 48 & 22 & 26 & 40 & $0.65 \pm 0.31$ & 1.20 & 0.23 & 0.30 & & & & \\
\hline Polyprion americanus & 32 & $66.2 \pm 8.9$ & 86 & 57 & 11 & 1 & $6.03 \pm 2.71$ & 12.20 & 3.60 & 0.89 & & 1.47 & & \\
\hline Pomadasys incisus & 365 & $28.9 \pm 7.7$ & 44 & 17 & 23 & 1380 & $0.55 \pm 0.32$ & 1.14 & 0.08 & 0.21 & & 1.26 & & \\
\hline
\end{tabular}




\begin{tabular}{|c|c|c|c|c|c|c|c|c|c|c|c|c|c|c|}
\hline Scientific name & & Size $(\mathrm{cn}$ & & & & We & ight (kg) & & & $\begin{array}{c}\text { Artesanal } \\
\text { catches } \\
(\%)\end{array}$ & $\begin{array}{c}\text { Porto } \\
\text { Santo } \\
(\%)\end{array}$ & $\begin{array}{l}\text { Recrea- } \\
\text { tive } \\
\text { catches } \\
(\%)\end{array}$ & $\begin{array}{l}\text { Indiv. } \\
\text { recreative } \\
\text { logbook } \\
(\%)\end{array}$ & $\begin{array}{c}\mathrm{kg} \\
\text { recreative } \\
\text { logbook } \\
(\%)\end{array}$ \\
\hline & \# & $\mathrm{Av}(\mathrm{SD})$ & Max & Min & $\begin{array}{l}\text { Samples } \\
\text { (number) }\end{array}$ & $\begin{array}{c}\text { Indiv } \\
\text { (number) }\end{array}$ & $\mathrm{Av}(\mathrm{SD})$ & Max & Min & $\begin{array}{l}(2013- \\
2019)\end{array}$ & $\begin{array}{l}(2013- \\
2016)\end{array}$ & & & \\
\hline Pomatomus saltatrix & 1 & 76 & 76 & 76 & 1 & 25 & 5.2 & & & 0.13 & 0.4 & 1.89 & 0.12 & 0.85 \\
\hline Pontinus kuhlii & 1986 & $25.9 \pm 4.4$ & 41 & 15 & 53 & 12 & $0.37 \pm 0.16$ & 0.80 & 0.16 & 2.98 & & 0.21 & & \\
\hline $\begin{array}{l}\text { Promethichthys } \\
\text { prometheus }\end{array}$ & 25 & $51.4 \pm 4.4$ & 59 & 44 & 3 & 10 & $0.66 \pm 0.12$ & 0.80 & 0.66 & 0.12 & & 0.21 & & \\
\hline Pseudocaranx dentex & 12 & $64.9 \pm 6.1$ & 76 & 51 & 10 & 3 & $3.74 \pm 1.44$ & 7.20 & 2.10 & 0.17 & 0.6 & 0.63 & & \\
\hline Ruvettus pretiosus & 3 & $89 \pm 4.6$ & 94 & 85 & 3 & 110 & $4.37 \pm 0.93$ & 5.00 & 3.30 & 0.14 & & & & \\
\hline Sarda sarda & 1 & 77 & 77 & 77 & 1 & 586 & 4.9 & & & 0.01 & & & 0.06 & 0.4 \\
\hline Sarpa salpa & & & & & & & & & & 0.09 & & 0.42 & & \\
\hline Schedophilus ovalis & & & & & & & & & & 0.03 & & & & \\
\hline Scomber colias & 110 & $36.9 \pm 5.1$ & 51 & 28 & 5 & 24 & $0.52 \pm 0.22$ & 0.88 & 0.27 & 0.45 & & 2.95 & 2.56 & 1.79 \\
\hline Scorpaena scrofa & 609 & $41.6 \pm 5.7$ & 55 & 22 & 103 & 4880 & $1.36 \pm 0.49$ & 3.60 & 0.50 & 1.41 & & 1.68 & 0.12 & 0.22 \\
\hline Seriola spp. & 97 & $64.4 \pm 15.1$ & 125 & 44 & 14 & 104 & $8.1 \pm 6.63$ & 25.40 & 1.60 & 3.11 & 3.2 & 6.95 & 0.97 & 7.73 \\
\hline Serranus atricauda & 5337 & $27.8 \pm 4.6$ & 84 & 13 & 139 & 1 & $0.34 \pm 0.42$ & 1.16 & 0.10 & 5.44 & 7.6 & 14.32 & 44.2 & 20.22 \\
\hline Setarches guentheri & & & & & & & & & & 0.01 & & & & \\
\hline Sparisoma cretense & & & & & & & & & & 1.18 & 1.0 & 2.53 & & \\
\hline Sparus aurata & & & & & & & & & & & & 0.21 & & \\
\hline Sphyraena viridensis & 104 & $80.3 \pm 8.5$ & 113 & 67 & 10 & 1 & $2.37 \pm 0.49$ & 3.20 & 1.60 & 2.00 & 13.5 & 3.16 & 1.22 & 5.37 \\
\hline $\begin{array}{l}\text { Spondyliosoma } \\
\text { cantharus }\end{array}$ & 1 & 50 & 50 & 50 & 1 & 2 & 2.2 & & & 0.02 & & & & \\
\hline Synodus saurus & 20 & $35 \pm 5.8$ & 47 & 25 & 2 & 496 & $0.4 \pm 0.12$ & 0.48 & 0.31 & 0.01 & & & & \\
\hline Thunnus alalunga & & & & & & & & & & 0.01 & & 0.84 & & \\
\hline Thunnus albacares & & & & & & & & & & 0.04 & & & & \\
\hline Thunnus obesus & 2 & $94 \pm 9.9$ & 101 & 87 & 1 & 3 & 14.6 & & & 1.20 & & 1.26 & & \\
\hline Trachinotus ovatus & & & & & & & & & & 0.01 & & 0.21 & 0.06 & \\
\hline Trachurus picturatus & 496 & $27.9 \pm 4.9$ & 44 & 16 & 12 & & $0.28 \pm 0.16$ & 0.51 & 0.10 & 0.30 & & 1.68 & 0.79 & 0.29 \\
\hline Trigla spp. & & & & & & & & & & 0.00 & & & & \\
\hline Xiphias gladius & & & & & & & & & & 0.14 & & & & \\
\hline Zeus faber & 3 & $61.7 \pm 11.2$ & 74 & 52 & 2 & & $3.33 \pm 1.8$ & 4.60 & 2.05 & 0.01 & & & & \\
\hline Unidentified & & & & & & & & & & 0.01 & & 0.021 & & \\
\hline CHONDRICTHYES & & & & & & & & & & & & 0.21 & & \\
\hline Deania spp. & 39 & $137.9 \pm 11.1$ & 162 & 115 & 20 & 4 & $12.87 \pm 4.9$ & 23.60 & 6.80 & 0.00 & & & & \\
\hline Galeorhinus galeus & & & & & & & & & & 2.01 & & & 0.42 & \\
\hline Heptranchias perlo & 1 & 109 & 109 & 109 & 1 & 3 & 15.2 & & & 0.01 & & & & \\
\hline Isurus oxyrinchus & 8 & $100.4 \pm 16$ & 120 & 82 & 4 & 24 & $5.43 \pm 2.14$ & 7.20 & 2.40 & 0.12 & & & & \\
\hline Mustelus mustelus & & & & & & & & & & 0.09 & & & & \\
\hline Odontaspsis ferox & 10 & $73.2 \pm 28.4$ & 130 & 36 & 5 & 1 & $3.35 \pm 1.26$ & 5.35 & 2.10 & 0.03 & & & & \\
\hline Rajiformes & 1 & 111 & 111 & 111 & 1 & 20 & 6.1 & & & 0.12 & & 0.42 & 3.04 & \\
\hline Sphyrna zygaena & & & & & & & & & & 0.01 & & & 0.12 & \\
\hline ARTHROPODA & & & & & & & & & & & & & & \\
\hline Decapoda & & & & & & & & & & & & & & \\
\hline Cancer bellianus & & & & & & & & & & 0.14 & & & & \\
\hline Chaceon affinis & & & & & & & & & & 0.03 & & & & \\
\hline Palinurus elephas & & & & & & & & & & 0.01 & & & & \\
\hline Plesionika spp. & & & & & & & & & & 0.02 & & & & \\
\hline Scyllarides latus & & & & & & & & & & 0.28 & & & & \\
\hline Cephalopoda & & & & & & & & & & & & & & \\
\hline Loligo vulgaris & 17 & $16.1 \pm 19.4$ & 88 & 8 & 6 & 491 & $2.58 \pm 2.08$ & 6.60 & 1.00 & 0.01 & & 0.21 & & \\
\hline Octopus vulgaris & & & & & & & & & & 0.17 & & 0.42 & 0.06 & \\
\hline Ommastrephidae & & & & & & & & & & 0.88 & & 0.42 & 0.3 & \\
\hline Sepia officinalis & & & & & & & & & & 0.00 & & & & \\
\hline Todarodes sagittatus & & & & & & & & & & 0.02 & & & & \\
\hline MOLLUSCA & & & & & & & & & & & & & & \\
\hline Gastropoda & & & & & & & & & & & & & & \\
\hline Patella spp. & & & & & & & & & & 0.06 & & 0.21 & & \\
\hline Phorcus sauciatus & & & & & & & & & & 0.01 & & & & \\
\hline
\end{tabular}




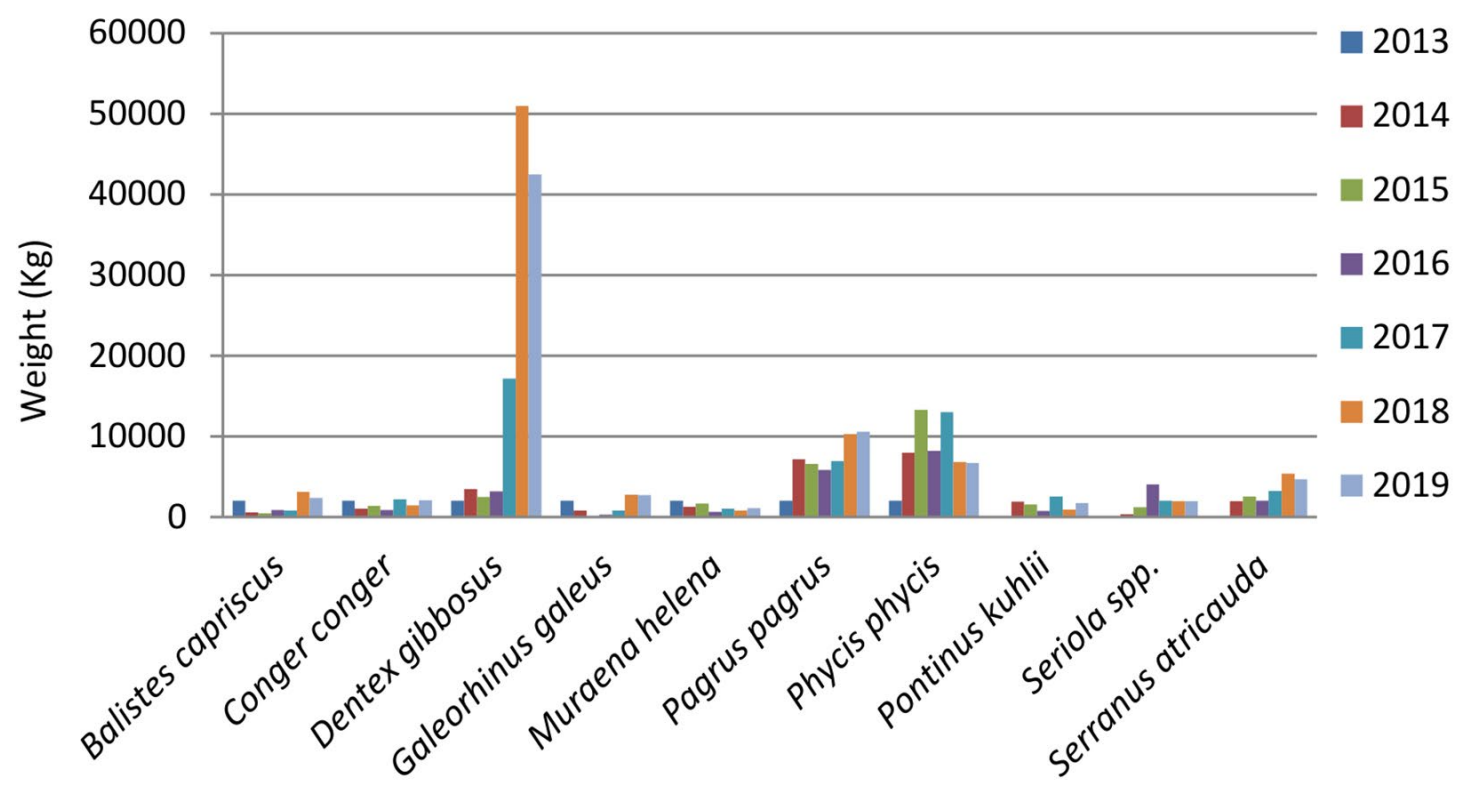

Fig. 3. - Landings (weight) of the most captured species by artisanal fishery and their evolution along the years (2013-2019).

\section{DISCUSSION}

\section{Fleet characteristics}

The artisanal fleet in the RAM targeting coastal fishes was relatively small, not exceeding 46 boats in all the years studied, and the boats (average LOA between 4.6 and $6.7 \mathrm{~m}$ according to the technique) usually had multipurpose licences allowing them to use different fishing gear for different target species.

Recreational boats showed a similar LOA (4.7 to $6.5 \mathrm{~m}$ ), but considering the number of licences requested by fishers in 2017, they constitute a much larger fleet, about 17 times the size of the artisanal fishing fleet (789 boats), although a decrease of $14.7 \%$ in the number of licences issued was observed from 2017 to 2019. According to the number of licences issued, the number of recreational boat fishers in Madeira represents around $0.3 \%$ of the population, which is a lower participation rate than either in mainland Portugal $(0.7 \%)$ or the Azores archipelago (1.1\%) in 2016 (Diogo et al. 2020). However, the number of people fishing recreationally by boat could be underestimated, as has been assessed for the whole recreational fishery in the Atlantic region and Europe (Hyder et al. 2018).

The interviews revealed that recreational boats tended to operate around $2 \mathrm{~nm}$ from the coast, while artisanal fishers combined fishing close to shore with trips to more distant fishing grounds, as also occurs in the Azores archipelago (Diogo and Pereira 2013). The commercial artisanal fishers commonly moved further away from the coast, sometimes reaching the Desertas Islands, the Barlavento Sea and Porto Santo. However, sometimes, particularly in winter due to worse weather conditions, artisanal fishers spent more time in shal- lower waters close to the coast overlapping the fishing grounds of recreational boat fishery.

Artisanal catches varied according to the technique employed and the most abundant catches were $D$. gibbosus with handline and rod and reel and P. phycis and $P$. pagrus with longlines. In recreational fishery, the main species caught using rod and reel and hand line were P. pagrus and Serranus atricauda (Günther, 1874), while the trolling technique was used to target large pelagic fishes.

Despite the relatively stable number of artisanal boats over time (except for a decrease in 2014), a noteworthy increase in the catches was observed. The number of fishing operations trebled from 2013 to 2019, reflecting the amount in $\mathrm{kg}$ of the annual catch, which in 2018-2019 was three times more than at the beginning of the study period (2013).

The increase in the number of fishing operations observed since 2017 seems to be related to the increase in the catches of $D$. gibbosus. The first record of this species in the RAM was in 1986, when a specimen was caught in the Bay of Funchal (Wirtz et al. 2008). From 2017, D. gibbosus became the main target species, surpassing $40 \mathrm{t}$ in 2018 and 2019, which would justify a study of the state of its population and how to control its captures. This increase may be associated with three factors: i) the size of this species, because the specimens captured usually had an average weight greater than three $\mathrm{kg}$ (Table 3); ii) its high economic value ( $€ 7.3 / \mathrm{kg}$ in 2017 , DRP data) in comparison with P. phycis ( $€ 2.85 / \mathrm{kg}$ ), S. atricauda ( $€ 5.18 / \mathrm{kg}$ ) and $P$. pagrus ( $€ 6.61 / \mathrm{kg}$ ); and iii) knowledge transmission between fishers of the specific techniques for capturing this species using L. vulgaris as live bait. Moreover, technological advances focusing on improving the efficiency in locating and catching fishes (Cook and Cowx 2006) 
may have contributed to the increase in catches over time. For example, the technique of squid hand-jig line described for recreational boat fishing changed over the decades due to improvements in gear technology, increasing the fishing efficiency thanks to blinking lights, as observed in Mediterranean Sea (Battaglia et al. 2010) and the Azores (Diogo and Pereira 2013).

Finally, the presence of nets, forbidden in the region, has sometimes been observed at some points near the coast (personal communication) and, even more worryingly, explosives, which are obviously illegal, were sometimes used in the region (personal communication).

\section{Catch species composition}

During the study period, 91 taxa were landed by the Madeiran artisanal fleet and 58 taxa were declared by recreational fishers. The number of species caught was much higher, because some genera and families (e.g. Seriola, Isthiophoridae, Mugilidae, Sphyraena and Synodus) encompass several species, and Chondrichthyes were recorded by order: i.e. rays can include individuals of Myliobatis aquila (Linnaeus, 1758) and of the genus Raja, Leucoraja, Dasyatis and Gymnura, and sharks captured by recreational fishery encompass various species. The capture of Chondrichthyes is not permitted in recreational fishing; so when sharks or rays were caught, they were usually released.

The results obtained from this study suggest that there is competition for marine resources between boat recreational and artisanal fisheries. In fact, the boat recreational fishery catches several highly valuable commercial species, including P. pagrus, S. atricauda and Seriola spp., directly competing with the artisanal fishery for the same resources. Catches of red porgy (P. pagrus) by recreational fishers probably also include some pink dentex (D. gibbosus), as they can be easily confused.

Artisanal fishers are able to use fishing gear that is prohibited in recreational fishery, allowing them to access a greater number of species and improve the effectiveness of catches. Moreover, unlike recreational fishery, the artisanal fishery does not have a maximum catch limit. However, a large overlap of species was observed between the two fisheries, and only five species caught in recreational fishing were not detected in the landings from artisanal fishery. The species absent in the artisanal catches were the non-indigenous species (D. labrax and S. aurata), marlins (mainly M. nigricans and T. albidus) captured by the big game fishing fleet (Martínez-Escauriaza et al. 2021) and garfish (B. belone). Intensive monitoring and biological studies are needed to evaluate the state of the stocks, in addition to reproductive, growth and other life history characteristics of the main target species. In addition, special attention should be given to vulnerable coastal species, especially long-lived and slow-growing ones with low reproductive potential (Cheung et al. 2005), such as Epinephelus marginatus (Lowe, 1834) and Scorpaena scrofa Linnaeus, 1758. These species serve as potential indicators of environmental health (Ferri et al. 2012), and their reduction contributes to altering the food web (Rochi et al. 2017).
Some of the most frequently caught species are sequential hermaphrodites. The disproportionate capture of one of the sexes may limit the production of eggs or sperm, leading to an imbalance in the population, as happened in northeastern Spain, where the mean landing size of this species was lower than the sex-change size, and only females were caught (Lloret et al. 2012). For example, P. pagrus is a protogynous hermaphrodite and in some localities has compensated for the effects of fishing by changing sex at smaller sizes (Harris and McGovern 1997, DeVries 2007). Also, protandric hermaphrodites such as Diplodus sargus (Linnaeus, 1758) and D. gibbosus, commonly caught by recreational and artisanal fisheries, respectively, need particular attention, because fisheries tend to target larger individuals, which are mostly female, and can thus have a disproportionate impact on the reproductive success of the population.

Chondrichthyes are particularly vulnerable to exploitation because of life history traits such as slow growth and low fecundity. For this reason, additional management and conservation measures are required. Although the capture of most of them is not allowed in recreational fishery (with the exception of Prionace glauca (Linnaeus, 1758) and Isurus oxyrinchus, Rafinesque, 1810), fishers sometimes caught some individuals, which were usually released. However, even if some fishes die due to the stressful angling techniques used (Arlinghaus et al. 2007), the mortality associated with this practice is thought to be low, and catch-and-release may be an effective measure in the management of the populations of these species (Cooke et al. 2013).

Finally, the technique of squid hand-jig line is quite selective, exclusively capturing cephalopods: $T$. sagittatus, S. pteropus, O. bartramii and L. vulgaris. This technique is usually performed in summer when these species migrate to near the RAM coasts, and several boat lights can be observed from the coast at night between July and August. The abundant amount of squid captured in this period (the legislation allows a maximum of $45 \mathrm{~kg}$, but some fishers admitted to catching more than $100 \mathrm{~kg}$ on some occasions) by the high number of boats does not correspond to the few landings recorded in fishing ports. This lack of records highlights the urgent need for studies focused on this fishery, keeping track of the catches, studying the dynamics of their populations, and if necessary proposing suitable regulations.

Among other invertebrates, the decapod crustaceans Palinurus elephas (Fabricius, 1787) and Scyllarides latus (Latreille, 1802) are included in the vulnerable exploited species list and should be under surveillance. In some European countries recreational fishers are not allowed to catch these and other decapod species due to their vulnerability, and in France even professional fishers are not allowed to catch $S$. latus (Lloret et al. 2020). Closed periods and minimum landing sizes are recommended for these species, as was established in the Azores (Decree $\mathrm{N}^{\circ}$ 74/2015). 


\section{Discrepancies in the reported fisheries data}

Erroneous reporting and underreporting of catches in coastal fisheries are problems that contribute to the lack of accurate information reflecting the real status of the target stocks and leading to inadequate conservation (Lloret et al. 2018). Part of the catch in the artisanal fisheries was used as bait, shared by the crew or consumed during the fishing trip. Consequently, total catches should be substantially higher than the landing statistics data (FAO 2015). Moreover, the existing data on daily landings by artisanal boats do not allow the technique used, the fishing grounds and the duration of the fishing events to be accurately determined, making it hard to calculate a suitable measure of fishing effort and CPUE. Thanks to the survey carried out, it was possible to obtain approximate data and to estimate fishing effort and CPUE for the gears used by the artisanal fishers.

Fishing effort, total catch and CPUE for recreational fishing were estimated on the basis of survey data (with a participation rate of $19.3 \%$ ) and were therefore subject to various biases associated with this type of sampling (NRC 2006, Groves et al. 2011). For example, during data collection some fishers refused to participate in the study. This reaction is common among fishers with no or few catches and causes a loss of part of information, generating deviation (Tarrant and Manfredo 1993). Moreover, among the respondents, a common error is caused by exaggerations in the information or failure to answer some questions. Another error is generated by fishers' memories. Fishers often remember past events poorly, especially as the time elapsed since the events increases, and very assiduous fishers may confuse past events with others (Zarauz et al. 2013). However, despite the deviation due to the accumulated bias, the final results allowed us to obtain an approximation of real values.

The results for recreational boat fishing showed that the CPUEs calculated for the hand line, rod and reel, trolling and long line varied between 1.39 and $2.08 \mathrm{~kg} /$ angler/h (Table 2), with an average of $1.42 \mathrm{~kg} /$ angler $/ \mathrm{h}$. In the Azores, the estimated average CPUE reported for recreational boat fishing is slightly higher, at $2.3 \mathrm{~kg} / \mathrm{an}-$ gler/h (Pico and Faial) (Diogo and Pereira 2013), and in northern Portugal it reaches $3.1 \mathrm{~kg} /$ angler/h (Lima 2006). However, these results are based on older data (more than 10 years old), so the comparisons must be taken with caution. Further studies to update the current CPUE values of other regions of Portugal are necessary to obtain a more accurate view of recreational boat fisheries in the country. However, it was possible to compare the CPUE and total catch of boat recreational fishery (this study) with the same values of other recreational fisheries of Madeira (shore angling and spearfishing) estimated for the same year, 2017 (Martínez-Escauriaza et al. 2020a,b). The CPUEs obtained for shore angling and spearfishing were both lower than those for boat fishing, with an average of $0.35 \mathrm{~kg} / \mathrm{angler} / \mathrm{h}$ and $1.1 \mathrm{~kg} / \mathrm{angler} / \mathrm{h}$, respectively. However, shore angling showed the highest total catch $(520.7 \mathrm{t})$, followed by spearfishing $(517.7 \mathrm{t})$ and boat fishing (509.8 t), owing to the number of li- cences issued for each modality in the same year (4825, 1778 and 789, respectively).

Artisanal fishery showed highly variable CPUE values because of the techniques employed and the target species. By contrast, the CPUE of traps showed no variability because it was obtained from only one survey and was therefore not representative. Because the knowledge on artisanal fisheries in Portugal is limited and focuses on specific target species or specific techniques (e.g. Pita et al. 2015, Pereira et al. 2019), it was not possible to compare our results with those of other studies. However, comparing the CPUEs estimated in the present study, artisanal fishery showed higher yields than recreational fishery. This may result in part from the higher mobility of the artisanal fleet, which reaches farther fishing grounds that may have a higher abundance of fish, presence of larger species and/or larger specimens. In addition, artisanal fishers can use a wider range of techniques which are not permitted in recreational fishing (e.g. longlines with a high number of hooks, traps and seine nets), and some of these have a high CPUE (Morato 2012).

Because in 2017 the number of artisanal fishery boats (SSF) was much lower than the number of recreational ones (42 vs. 789), the total catches also reflected this trend, with $62.3 \mathrm{t}$ for artisanal and $509.8 \mathrm{t}$ for recreational fishery. However, the present study did not involve the total catch from the three artisanal purse seiners, estimated at between 942.90 and $1047.82 \mathrm{t}$ from October 2016 to December 2017 (Tejerina et al. 2019). Considering only this value, the total catch of artisanal fishery would be higher than the total catch of recreational boat fishing. However, adding the estimated catches of recreational boat fishery, shore angling and spearfishing (a total of almost $1500 \mathrm{t}$ ), the final weight of catches would be considerably higher than the artisanal one. This result suggests that in Madeira the recreational fishery may have a higher impact than the artisanal fishery on the most frequently caught species. Although the commercial fishery is usually considered the main cause of the decline in stocks of many species (Lloret et al. 2018), the results of this study support the idea that recreational fishing may negatively affect the fauna and ecosystems of Madeira, as suggested for other areas of the world (Coleman et al. 2004, Cooke and Cowx 2004, 2006).

\section{Recreational boat fishers' characteristics and opinions}

The recreational fishers interviewed were mostly local residents, and only a few foreigners were encountered during the surveys. The characteristics of typical Madeiran recreational boat anglers (mostly middle-age and males) were similar to those of other regions of Portugal (Lima 2006, Diogo and Pereira 2013) and several areas of the Mediterranean Sea (Morales-Nin et al. 2005, Pawson et al. 2006, Lloret et al. 2008, Battaglia et al. 2010). The almost total absence of women practising this activity was confirmed in the present study, with the sole exception of one woman interviewed. The absence or low number of women fishers is a recurrent 
characteristic of recreational boat fishing, as observed in other studies from different parts of the world (Lloret et al. 2008, Diogo and Pereira 2013, Ryan et al. 2013). This contrasts with the relatively high proportion of women fishers in Madeira (in comparison with other regions), around $10 \%$, but they are mostly restricted to other modalities, especially shore angling and limpet collection (Martínez-Escauriaza et al. 2020a, Hermida and Costa 2020). The average age of recreational boat fishers was similar to that of shore angling fishers (42.9; Martínez-Escauriaza et al. 2020a), but they were older than spearfishers, an activity which tends to attract younger people with an average age of 32.8 (Martínez-Escauriaza et al. 2020b).

As expected, the mean expenditure by the owners of recreational fishing boats was higher (€763.1 per year) than that reported for the other modalities practised in the region: spearfishing (€465.4) and shore angling (€254) (Martínez-Escauriaza et al. 2020a,b).

Among all the recreational fishing modalities, a higher percentage of boat fishers $(8.5 \%)$ admitted to selling their catches, followed by spearfishers $(6.9 \%$; Martínez-Escauriaza et al. 2020b) and shore anglers (3.5\%; Martínez-Escauriaza et al. 2020a). This percentage is surely underestimated for all the modalities, because many fishers who sell their catch illegally are reluctant to admit it in a questionnaire. In a recent study on fish consumption habits in Madeira, almost $15 \%$ of people admitted to buying fish directly from fishers (Hermida and Costa 2020). Illegal sale of catches by recreational boat fishers was identified as the main problem for the Azores fishery, because $10.3 \%$ of fishers sold part of their catches. This problem was partly addressed in 2008 with an implementation of new specific regulations for recreational boat fishing (Diogo and Pereira 2013). Similar action was adopted in the RAM only in late 2016 (Decree $\mathrm{N}^{\circ}$ 484/2016), but further inspections and more controls by authorities are needed to reduce black market practices and overfishing related to it.

It is also hard to separate true recreational fishing from subsistence fishing; the very high percentage of recreational boat fishers who report consuming the catch certainly indicates that this may be a strong motivation for engaging in this activity. In a previous study (Hermida and Costa 2020), 7\% of the population reported engaging in subsistence fishing (i.e. fishing for personal consumption), but the proportion of people who participated in informal fish acquisition (including fishing for consumption, buying directly from the fisher and obtaining fish from family and friends who fish) was much higher (35\%).

\section{FINAL COMMENTS}

Our results show that recreational and artisanal fishing share a great proportion of targeted species, exerting a combined pressure on many of them. The significant impact of recreational fishing in Madeira should not be neglected, and may even be higher than the impact of commercial artisanal fishing, at least for many coastal species. For this reason, recreational fisheries data should be incorporated into stock assessments and fisheries and coastal zone management plans, as proposed by Cooke et al. (2006). We suggest the requirement of continued monitoring of artisanal and recreational boat fishing in the RAM by developing and improving data collection using appropriate methods, such as onboard observers, survey programmes and cooperation between stakeholders (Lloret et al. 2018). The involvement of recreational fishing clubs and associations in the decision-making process should also be promoted (Veiga et al. 2013). Moreover, fisheries managers should include seasonal fisheries closures during the reproductive season of the most vulnerable target species, as suggested by Sadovy de Mitcheson et al. (2013). It would also be useful to develop environmental education plans for fishers to raise awareness about the negative impacts of intensive capture of some species. Finally, there is an urgent need to increase control of recreational captures, including the bag limit and maximum landing sizes, and to intensify inspection to avoid illegal sale.

\section{ACKNOWLEDGEMENTS AND FUNDING}

The authors wish to thank all the fishers who so kindly collaborated in this study. We also thank Gustavo Silva for drawing up the maps and Fernando Alexandre for revising the English.

RM was financially supported by the Oceanic Observatory of Madeira Project (M1420-01-0145-FEDER000001-Observatório Oceânico da Madeira-OOM). FG was supported by a post-doctoral research fellowship granted by ARDITI in the framework of the project RAGES [ARDITI-RAGES-2019-001]. MH was financially supported by a postdoctoral grant from the Regional Agency for Development of Research, Technology and Innovation of Madeira (ARDITI), Project M1420-09-5369-FSE-000001.

\section{REFERENCES}

Arlinghaus R., Cooke S.J., Lyman J., et al. 2007. Understanding the complexity of catch-and-release in recreational fishing: an integrative synthesis of global knowledge from historical, ethical, social, and biological perspectives. Rev. Fish. Sci. Aquac. 15: 75-167. https://doi.org/10.1080/10641260601149432

Battaglia P., Romeo T. Consoli P., et al. 2010. Characterization of the artisanal fishery and its socio-economic aspects in the central Mediterranean Sea (Aeolian Islands, Italy). Fish. Res. 102: 87-97. https://doi.org/10.1016/j.fishres.2009.10.013

Castro J.J., Divovich E., Delgado de Molina Acevedo A., et al. 2019. Reconstruction of marine small-scale fisheries captures in the Canary Islands (NE Atlantic Ocean) from 1950 to 2010. Sci. Mar. 83: 7-17. https://doi.org/10.3989/scimar.04837.18A

Cheung W.W., Pitcher T. J., Pauly D. 2005. A fuzzy logic expert system to estimate intrinsic extinction vulnerabilities of marine fishes to fishing. Biol. Conserv. 124: 97-111. https://doi.org/10.1016/j.biocon.2005.01.017

Coleman F.C., Figueira W.F., Ueland J.S., et al. 2004. The impact of United States recreational fisheries on marine fish populations. Science 305: 1958-1960. https://doi.org/10.1126/science.1100397

Costanza R., d'Arge R., de Groot R.S., et al. 1997. The value of the world's ecosystem services and natural capital. Nature. 387: $253-260$.

https://doi.org/10.1038/387253a0 
Cooke S.J., Danylchuk A.J., Danylchuk S.E., et al. 2006. Is catch and release recreational angling compatible with no-take marine protected areas? Ocean Coast. Manag. 49: 342-354. https://doi.org/10.1016/j.ocecoaman.2006.03.003

Cooke S.J., Donaldson M.R., O'connor C.M., et al. 2013. The physiological consequences of catch-and-release angling: perspectives on experimental design, interpretation, extrapolation and relevance to stakeholders. Fish. Manag. Ecol. 20: $268-287$ https://doi.org/10.1111/j.1365-2400.2012.00867.

Cooke S. J., Cowx I. G. 2004. The role of recreational fishing in global fish crises. Bioscience. 54: 857-859. https://doi.org/10.1641/0006-3568(2004)054[0857:TRORFI]2.0.CO;2

Cooke S.J., Cowx I.G. 2006. Contrasting recreational and commercial fishing: searching for common issues to promote unified conservation of fisheries resources and aquatic environments. Biol. Conserv. 128: 93-108. https://doi.org/10.1016/j.biocon.2005.09.019

Correia F.N., Mendes J.M. (orgs.) 2000. Plano Regional da Política de Ambiente. OpçõesEstratégicas e Medidas de Intervenção, Funchal, Secretaria Regional do Ambiente e dos Recursos Naturais.

DeVries D.A. 2007. No evidence of bias from fish behavior in the selectivity of size and sex of the protogynous red porgy (Pagrus pagrus, Sparidae) by hook-and-line gear. Fish. Bull. 05: 582-587.

DGRM- de RecursosNaturais, D. G. Segurança e ServiçosMarítimos, do Ministério do Mar, do Governo de Portugal. 2018. Ordenamento do EspaçoMarítimo Nacional-Plano de Situação [National Maritime Spatial Planning-Situation Plan] (Volumes I to VI)

Diogo H., Pereira J.G. 2013. Recreational boat fishing pressure on fish communities of the shelf and shelf break of Faial and Pico Islands (Azores Archipelago): implications for coastal resource management. Acta Ichthyol. Piscat. 43: 267. https://doi.org/10.3750/AIP2013.43.4.02

Diogo H., Veiga P., Pita C., et al. 2020. Marine recreational fishing in Portugal: Current knowledge, challenges, and future perspectives. Rev. Fish. Sci. Aquac. 28: 536-560. https://doi.org/10.1080/23308249.2020.1777083

European Parliament. 2014. Regulation (EU) No 508/2014 of the European Parliament and of the Council of 15 May 2014 on the European Maritime and Fisheries Fund and repealing Council Regulations (EC) No 2328/2003, (EC) No 861/2006, (EC) No 1198/2006 and (EC) No 791/2007 and Regulation (EU) No 1255/2011 of the European Parliament and of the Council

FAO. 2015. Report of the Expert workshop to estimate the magnitude of illegal, unreported and unregulated fishing globally, FAO, Rome, 2-4 February 2015. http://www.fao.org/3/a-i5028e.pdf

Ferri J., Stagličić N., Matić-Skoko S. 2012. The black scorpionfish, Scorpaena porcus (Scorpaenidae): Could it serve as a reliable indicator of Mediterranean coastal communities' health?. Ecol. Indic. 18: 25-30. https://doi.org/10.1016/j.ecolind.2011.11.004

Font T. Lloret J., Piante C. 2012. Recreational Fishing within Marine Protected Areas in the Mediterranean. MedPAN North Project. WWF, France. 168 pp.

Groves R.M., Fowler Jr F.J., Couper M.P., et al. 2011. Survey methodology. John Wiley \& Sons, Hoboken, New Jersey, $451 \mathrm{pp}$

Harris P.J., McGovern J.C.1997. Changes in the life history of red porgy, Pagrus pagrus, from the southeastern United States, 1972-1994. Fish. Bull. 95: 732-747.

Hermida M., Costa S. 2020. Between Tradition and Taste: Fish Consumption Habits in a Small Portuguese Archipelago. J. Aquat. Food Prod. Technol. 29: 335-349. https://doi.org/10.1080/10498850.2020.1734892

Hermida M., Delgado J. 2016. High trophic level and low diversity: Would Madeira benefit from fishing down? Mar. Policy. 73: $130-137$. https://doi.org/10.1016/j.marpol.2016.07.013

Hyder K., Weltersbach M.S., Armstrong M., et al. 2018. Recreational sea fishing in Europe in a global context - participation rates, fishing effort, expenditure, and implications for monitoring and assessment. Fish Fish. 19: 225-243. https://doi.org/10.1111/faf.12251
Lazzari N., Becerro, M.A., Sanabria-Fernandez J.A., MartínLópez B. 2021. Assessing social-ecological vulnerability of coastal systems to fishing and tourism. Sci. Total Environ. 784: 147078 https://doi.org/10.1016/j.scitotenv.2021.147078

Lima D.R. 2006. Caracterização da Pesca Recreativa de Alto Mar, a Região Norte de Portugal [BC thesis]. Leiria (Portugal): Instituto Politécnico de Leiria.

Lloret J., Zaragoza N., Caballero D., Riera V. 2008. Biological and socioeconomic implications of recreational boat fishing for the management of fishery resources in the marine reserve of Cap de Creus (NW Mediterranean). Fish. Res. 91: 252-259. https://doi.org/10.1016/i.fishres.2007.12.002

Lloret J., Muñoz M., Casadevall M. 2012. Threats posed by artisanal fisheries to the reproduction of coastal fish species in a Mediterranean marine protected area. Estuar. Coast. Shelf Sci. 113: 133-140. https://doi.org/10.1016/j.ecss.2012.07.015

Lloret J., Cowx I. G., Cabral H., et al. 2018. Small-scale coastal fisheries in European Seas are not what they were: ecological, social and economic changes. Mar. Policy. 98: 176-186. https://doi.org/10.1016/j.marpol.2016.11.007

Lloret J., Biton-Porsmoguer S., Carreño A., et al. 2020. Recreational and small-scale fisheries may pose a threat to vulnerable species in coastal and offshore waters of the western Mediterranean. ICES J Mar Sci. 77: 2255-2264. https://doi.org/10.1093/icesims/fsz071

Martínez-Escauriaza R., Hermida M., Villasante S., et al. 2020a. Importance of recreational shore angling in the archipelago of Madeira, Portugal (northeast Atlantic). Sci. Mar. 84: 331-341. https://doi.org/10.3989/scimar.05046.30A

Martínez-Escauriaza R., Vieira C., Gouveia L., et al. 2020b. Characterization and evolution of spearfishing in Madeira archipelago, Eastern Atlantic. Aquat. Living Resour. 33: 15. https://doi.org/10.1051/alr/2020015

Martínez-Escauriaza R., Pita P., de Gouveia M.L.F., et al. 2021. Analysis of Big Game Fishing Catches of Blue Marlin (Makaira nigricans) in the Madeira Archipelago (Eastern Atlantic) and Factors that Affect Its Presence. Sustainability. 13: 8975. https://doi.org/10.3390/su13168975

Mata J., Fonseca P.E., Prada S., et al. 2013. III. 8.2. O arquipélago da Madeira. Geologia de Portugal, 2.

Morales-Nin B., Moranta J., García C., et al. 2005. The recreational fishery off Majorca Island (western Mediterranean): some implications for coastal resource management. ICES J. Mar. Sci. 62: 727-739. https://doi.org/10.1016/j.icesims.2005.01.022

Morales-Nin B., Grau A.M., Palmer M. 2010. Managing coastal zone fisheries: a Mediterranean case study. Ocean. Coast. Manag. 53: 99-106. https://doi.org/10.1016/j.ocecoaman.2010.01.003

Morato T. 2012. Description of environmental issues, fish stocks and fisheries in the EEZs around the Azores and Madeira. Report for the European Commission, Directorate-General Maritime Affairs and Fisheries, B-1049 Brussels, Belgium. Available online at:

https://stecf.jrc.ec.europa.eu/documents/43805/465474/ Item+6.2+Report+Morato_Azores_Madeira.pdf

National Research Council (NRC). 2006. Review of recreational fisheries survey methods. National Research Council. National Academy of Science Press. Washington, USA. $187 \mathrm{pp}$.

Pawson M.G., Tingley D., Padda G., Glenn H. 2006. Sport fisheries (or marine recreational fisheries) in the EU. EU contract FISH/2004/011 662, Cefas, Lowestoft, UK, 242 pp.

Pereira F., Vasconcelos P., Moreno A., Gaspar M.B. 2019. Catches of Sepia officinalis in the small-scale cuttlefish trap fishery off the Algarve coast (southern Portugal). Fish. Res. 214: 117-125. https://doi.org/10.1016/j.fishres.2019.01.022

Pita C., Pereira J., Lourenç S., et al. 2015. The traditional small-scale octopus fishery in Portugal: framing its governability. In: Jentoft, S., Chuenpagdee, R. (eds) Interactive governance for small-scale fisheries. Springer, Cham, $25 \mathrm{pp}$. https://doi.org/10.1007/978-3-319-17034-3_7

Pita P., Hyder K., Gomes P., et al. 2018. Economic, social and ecological attributes of marine recreational fisheries in Galicia. Spain. Fish. Res. 208: 58-69. https://doi.org/10.1016/j.fishres.2018.07.014 
Rocchi M., Scotti M., Micheli F., Bodini A. 2017. Key species and impact of fishery through food web analysis: a case study from Baja California Sur, Mexico. J. Mar. Syst. 165: 92-102. https://doi.org/10.1016/i.jmarsys.2016.10.003

Ryan K.L., Wise B.S., Hall N.G., et al. 2013. An integrated system to survey boat-based recreational fishing in Western Australia 2011/12. Fisheries Research Division, Western Australian Fisheries and Marine Research Laboratories. $162 \mathrm{pp}$.

Sadovy de Mitcheson Y., Craig M.T., Bertoncini A.A., et al. 2013. Fishing groupers towards extinction: a global assessment of threats and extinction risks in a billion dollar fishery. Fish Fish. 14: 119-136. https://doi.org/10.1111/j.1467-2979.2011.00455.x

Shon S., Delgado J.M., Morato T., et al. 2015. Reconstruction of marine fisheries catches for Madeira Island, Portugal from 1950-2010. Fisheries Centre Working Paper \#2015-52, University of British Columbia, Vancouver, 13 pp.

Suchanek T.H. 1994. Temperate coastal marine communities: biodiversity and threats. Am. Zool. 34: 100-114. https://doi.org/10.1093/icb/34.1.100

Tarrant M.A., Manfredo M.J. 1993. Digit preference, recall bias, and nonresponse bias in self reports of angling participation. Leis. Sci. 15: 231-238.

https://doi.org/10.1080/01490409309513202
Tejerina R., Hermida M., Faria G., Delgado J. 2019. The purseseine fishery for small pelagic fishes off the Madeira Archipelago. Afr. J. Mar. Sci. 41: 373-383. https://doi.org/10.2989/1814232X.2019.1678520

Veiga P., Pita C., Leite L., et al. 2013. From a traditionally open access fishery to modern restrictions: Portuguese anglers' perceptions about newly implemented recreational fishing regulations. Mar. policy. 40: 53-63. https://doi.org/10.1016/j.marpol.2012.12.037

Wirtz P., Fricke R., Biscoito M. 2008. Coastal fishes of Madeira Island - New records and an annotated check-list. Zootaxa. 1715:1-26. https://doi.org/10.11646/zootaxa.1715.1.1

Zarauz L., Prellezo R., Mugerza E., et al. 2013. Analysis of the recreational and fishing fleet in the Basque Country and its socioeconomic impact. Revista de Investigación Marina (Marine Research Journal). 20: 38-70.

Zeller D., Darcy M., Booth S., et al. 2008. What about recreational catch?: Potential impact on stock assessment for Hawaii's bottomfish fisheries. Fish. Res. 91: 88-97. https://doi.org/10.1016/j.fishres.2007.11.010 